\title{
Neonatal Intensive Care Nurses' Opinion on Oxygen Therapy: A Survey Conducted In Turkey
}

\section{Yenidoğan Yoğun Bakım Hemşirelerinin Oksijen Tedavisi Hakkında Görüşleri: Türkiye'de Yapılan Bir Araştırma}

\author{
Fatma Taș Arslan ${ }^{1}$, Sevil Özkan ${ }^{1}$, Bedriye $\mathrm{Ak}^{2}$, Gonca Karayağız Muslu ${ }^{3}$
}

1Selçuk Üniversitesi Sağlik Bilimleri Fakültesi Hemşirelik Bölümü Çocuk Sağliği AD, Konya

2Abant İzzet Baysal Üniversitesi Bolu Sağlık Yüksekokulu, Bolu.

3Muğla Sıtkı Koçman Üniversitesi Fethiye Sağlık Bilimleri Fakültesi Hemşirelik Bölümü, Muğla.

öz

Amaç: Yenidoğan hemşirelerinin oksijen tedavisi hakkındaki görüşleri ve bilgilerini belirlemektir.

Gereç ve Yöntem: Tanımlayıcı çalışma Türkiye Konya'da bulunan dört yenidoğan yoğun bakım ünitesinde (YYBÜ) yürütüldü. Araştırmayı kabul eden 80 hemşire çalışmaya dahil edildi. Veriler anket kullanılarak toplandı. Anket 30 sorudan oluşmaktaydı.

Bulgular: YYBÜ'lerinde oksijen tedavi yöntemlerine ilişkin protocol yoktu. Çalışmada $\mathrm{SpO} 2$ ve kan gazı değerleri, yenidağanlarda solunum sıkıntısı, dolaşımın değerlendirilmesi ve hekim istemi olması oksijen tedavisi için hemşireler tarafından önemli olduğu bulunmuştur. "Endotrakeal aspirasyon öncesi oksijen verilmesi", "oksijen tadavisinin durdurulmasında oksijen akış hızının yavaş yavaş azaltılarak sonlandırılması" ve "oksijen nemlendirilmesinde kullanılan sıvının türü" hemşireler tarafından en çok bilinen sorulardır.

Sonuç: Yenidoğan hemşirelerinin oksijen tadavisinin bazı yönleri hakkında yeterli bilgiye sahip olduğu ancak bazı konularda ise önemli bilgi eksiklikleri vard.

Anahtar Kelimeler: YYBÜ, oksijen tedavisi, yenidoğan hemşiresi

\section{ABSTRACT}

Aim: To determine neonatal intensive care nurses' opinion on oxygen therapy and their knowledge about it.

Methods: This descriptive study was conducted at five neonatal intensive care units (NICUs) in Konya, Turkey. 80 nurses, who agreed to participate, were included in study. Data were collected using a questionnaire. The questionnaire consisted of 30 questions.

Results: There wasn't any protocol that indicates methods for oxygen therapy in these NICUs. Values of $\mathrm{SpO} 2$ and blood gas, neonates' respiratory distress, circulatory assessment for neonates and physician's request were found important for nurses for oxygen therapy. "Performing pre-oxygenation before endotracheal aspiration", "reducing gradually flow rate of oxygen while stopping oxygen therapy", "the type of fluid for humidifying the oxygen" were the most known questions by nurses.

Conclusion: Neonatal nurses had adequate knowledge on some aspects of oxygen therapy, but they also had incomplete knowledge in some vital issues for oxygen therapy.

Keywords: NICU, oxygen therapy, neonatal nurse 


\section{INTRODUCTION}

Oxygen therapy, which is a routine treatment procedure in Neonatal Intensive Care Units (NICUs), has principal objectives like reducing the patient's respiratory and cardiac workload, increasing cardiac output, hemodynamic efficiency and alveolar pressure, preventing tissue hypoxia and mortality (1-4). In order to achieve all these objectives for neonates, oxygen therapy must be performed after having evaluated the efficacy, risks and pulmonary effects (5). In the process of this evolution, decisions to initiate oxygen therapy for respiratory distress is influenced by different situations such as abnormal blood gas measurements, increased respiratory workload, blood pressure, respiratory rate changes, anemia and falling oxygen saturation- $\mathrm{SpO}_{2}$ $(6,7)$.Furthermore, oxygen therapy methods for neonates must be more effective and less invasive (8-10). However, factors such as the patient's general condition, unit routines, physician's preferences and the nurses' familiarity with oxygen delivery devices influence methods of oxygen administration (11). For example, Eastwood et al. (2012) found that nurses had huge influence in the process of choosing methods of oxygen administration. In the same study, it was found that nurses made their decisions according to patient's comfort (98.1\%) and treatment costs $(1.9 \%)(8)$.

Processes of evaluation and decision making must be completed as soon as possible. Because errors and delays in the decisions of oxygen therapy may cause a progression of hypoxemia and respiratory dysfunction, which lead to death of neonate (12).However, inappropriate oxygen therapy may cause health problems such as retinopathy of prematurity (ROP), transporting less oxygen to tissues, hypoxia, pulmonary vasoconstriction, atelectasis and release of free oxygen radicals $(8-10)$.

Even though effective oxygen therapy for neonates remains a primary duty for all health care professionals, significance and responsibilities of nurses in this process cannot be ignored (7). Therefore, neonatal intensive care nurses have the duty of possessing the necessary knowledge and skills for oxygen therapy in the interest of neonates' safety. Due to uncertain legal framework, various questions (such as "Who is going to decide the oxygen therapy?", "Which criteria must be used for decision?" "What level of training and qualification for oxygen administration do nurses need?") remain unanswered in NICUs. Furthermore, studies about neonatal intensive care nurses' current state are limited in number not only in national level, but also in worldwide $(13,14)$. Moreover, these studies are generally focused on specialized questions like comparisons between two oxygen delivery devices efficacy. There is a need for studies which investigate the current level of knowledge and skill from a more general perspective. Therefore, this study aims to describe neonatal intensive care nurses' opinion and their current knowledge on oxygen therapy.

\section{MATERIAL AND METHODS}

\section{Population and Sampling}

This descriptive study was conducted at five neonatal intensive care units in Konya, Turkey. The population of study is 118 nurses who were working in these neonatal intensive care units (NICUs). Without sample selection, 80 nurses $(67.8 \%)$, who agreed to participate, were included in the study sample.

\section{Data Collection}

Data were collected through interviews with the nurses using a questionnaire developed by the researchers on the basis of published literature $(8,12,15-18)$. The questionnaire consisted of 30 questions and it was divided in two parts: socio-demographic characteristics (total eight questions such as; age, educational level, years worked in nursing etc.); and opinions on the oxygen 
administration for neonates (total 22 questions). Opinions parts of questionnaire included several open-ended questions. Some of these were:

- What are the most common complications for neonates in the process of oxygen administration?

- Which liquid is used for humidification of oxygen?

Opinion of experts of the survey questionnaire was assessed by three nurse educators ( $\mathrm{PhD}$ degree in pediatric nursing) and two neonatal intensive care nurses working in field. The questionnaire form was revised according to their feedback.

Before beginning the study, participants were informed about the purpose of this study and their participation was voluntary. From 118 neonatal intensive care nurses, while 80 agreed to participate, 38 either did not agree to participate or could not be reached. Data collection form was delivered to NICU nurses and it was collected from them via face-to-face interview technique. The questionnaire was answered in 10 to 15 minutes by the nurses.

\section{Evaluation of Data}

Descriptive evaluation of the collected data was performed by computer and consisted of number, percentiles, mean and standard deviation for each characteristic.

\section{Ethics}

A letter of approval from the Ethics Committee of the Selcuk University Faculty of Health Sciences was obtained before starting to the study. The participants of the study gave their verbal consent, after they were informed the purpose of study.

\section{RESULTS}

The characteristics of the participants were distributed as follows: $41.3 \%$ were aged 32 and over (average age of all subjects $29.23 \pm 6.01$ );
$65.0 \%$ had a baccalaureate degree, $45.0 \%$ had 6 years or longer professional experience (with a general average of $8.08 \pm 6.55$ ); $50.0 \%$ had already worked in the neonatal intensive care unit for 2-5 years (general average 4.03 \pm 4.57 ). Also, $28.7 \%$ of participants had a neonatal nursing certificate, while $60.0 \%$ had attended a neonatal resuscitation program. The study showed that these neonatal intensive care units had no protocol to indicate the methods of oxygen administration. The need for an accurate protocol about oxygen administration was indicated by $93.8 \%$ of nurses. Also they stated that the following health professionals could take part in the development of protocol: physicians $(\mathrm{n}=54,67.5 \%)$; nurses $(\mathrm{n}=24$, $30.0 \%)$; administration nurses ( $\mathrm{n}=9,11.3 \%)$ and academic scientists in nursing division $(\mathrm{n}=9,11.3 \%)$ (Table 1).

The most frequently used methods of oxygen therapy were found to be as follows: directly via the incubator $(\mathrm{n}=52,65.0 \%)$, through a nasal cannula $(\mathrm{n}=15,19.0 \%)$ and by nasal continuous positive airway pressure (nCPAP) $\quad(n=8,10.0 \%)$. The order of precedence in the neonatal nurses' choice about devices of oxygen therapy was "nasal cannula or nCPAP" ( $\mathrm{n}=36,45.0 \%)$, "oxygen hood" (n=36, 45.0\%), and "direct administration via incubator" $(\mathrm{n}=6,7.5 \%)$. $\mathrm{SpO}_{2}$ level (57.5\%), neonatal respiratory distress $(40.0 \%)$ and the physician's request (37.5\%) were the factors which influenced the decision to initiate oxygen therapy. Nurses considered primarily $\mathrm{SpO}_{2}$ value $(65.0 \%)$, physician's written or verbal request $(38.8 \%)$ and cardiovascular status of neonate $(5.0 \%)$ in the process of determining oxygen concentration and flow rate. When a neonate's $\mathrm{SpO}_{2}$ level decreased; $71.1 \%$ of participants started oxygen therapy with their own decision and only $5.0 \%$ of participants gave information to physician about situation. In the study, also, the efficacy of oxygen therapy for neonate was characterized by $\mathrm{SpO}_{2}$ level (78.8\%) and blood gases $(52.5 \%)$. It was determined that during oxygen therapy, $43.8 \%$ of nurses paid 
attention to the amount of oxygen administered, $11.2 \%$ to the humidification level and another $11.2 \%$ to the $\mathrm{SpO}_{2}$ measurement (Table 2).

Table 1. Information about demographic characteristics of participants and NICU $(n=80)$

\begin{tabular}{|c|c|c|}
\hline \multicolumn{2}{|l|}{ Characteristics } & $\%$ \\
\hline \multicolumn{3}{|l|}{ Age (Mean \pm s.d. $=29.23 \pm 6.01)$} \\
\hline 20-25years & 29 & 36.3 \\
\hline 26-31years & 18 & 22.5 \\
\hline 32 and more years & 33 & 41.3 \\
\hline \multicolumn{3}{|l|}{ Education } \\
\hline Vocational high schools & 17 & 21.3 \\
\hline $\begin{array}{l}\text { Two years associated agree nursing } \\
\text { programs }\end{array}$ & 11 & 13.7 \\
\hline Baccalaureate degree & 52 & 65.0 \\
\hline \multicolumn{3}{|l|}{$\begin{array}{l}\text { Year of Practice as a Nurse (Mean } \pm \\
\mathrm{sd}=8.08 \pm 6.55)\end{array}$} \\
\hline 1 year or less & 20 & 25.0 \\
\hline $2-5$ years & 24 & 30.0 \\
\hline 6 years and more & 36 & 45.0 \\
\hline \multicolumn{3}{|c|}{$\begin{array}{l}\text { Years of Practice in Neonatal Intensive Care Units } \\
(\text { Mean } \pm \mathrm{sd}=4.03 \pm 4.57)\end{array}$} \\
\hline 1 year or Less & 25 & 31.3 \\
\hline $2-5$ years & 40 & 50.0 \\
\hline 6 years and more & 15 & 18.7 \\
\hline \multicolumn{3}{|l|}{ Having Neonatal Nursing Certificate } \\
\hline Yes & 23 & 28.7 \\
\hline No & 57 & 71.3 \\
\hline \multicolumn{3}{|l|}{ Attending to NRP Course * } \\
\hline Yes & 48 & 60.0 \\
\hline No & 32 & 40.0 \\
\hline \multicolumn{3}{|l|}{$\begin{array}{l}\text { Having a Protocol to Indicate the } \\
\text { Methods of Oxygen Administration in } \\
\text { NICU }\end{array}$} \\
\hline Yes & 0 & 0 \\
\hline No & 80 & 100 \\
\hline \multicolumn{3}{|l|}{$\begin{array}{l}\text { Needing a Protocol to Indicate the } \\
\text { Methods of Oxygen Administration in } \\
\text { NICU }\end{array}$} \\
\hline Yes & 75 & 93.8 \\
\hline No & 5 & 5.2 \\
\hline \multicolumn{3}{|l|}{$\begin{array}{l}\text { Health Professionals who could take } \\
\text { part in development of protocol } * *\end{array}$} \\
\hline Physician & 54 & 67.5 \\
\hline Nurse & 24 & 30.0 \\
\hline Administration Nurse & 9 & 11.3 \\
\hline Academic Scientists in Nursing Division & 9 & 11.3 \\
\hline
\end{tabular}

A few nurses (8.8\%) knew the correct answer question about approximate amount of oxygen that was given to neonate at $1 \mathrm{~L} / \mathrm{min}$ a flow rate. Changing in the oxygen amount received by the neonate according to using different devices for oxygen therapy was responded correctly $71.2 \%$ of nurses. Questions about oxygen flow rate $(\mathrm{L} / \mathrm{min})$ were asked and correct answers changed $1.3 \%$ for high flow rate and $5.0 \%$ for low flow rate oxygen therapy.

Table 2. Nurses' practices and opinions about oxygen therapy

\begin{tabular}{|c|c|c|}
\hline & $\mathbf{n}$ & $\%$ \\
\hline \multicolumn{3}{|l|}{ Used Methods for Oxygen Therapy } \\
\hline Directly via the incubator & 52 & 65.0 \\
\hline Nasal Cannula & 15 & 19.0 \\
\hline $\begin{array}{l}\text { Nasal Continous positive airway pressure } \\
\text { (nCPAP) }\end{array}$ & 8 & 10.0 \\
\hline No answer & 5 & 6.0 \\
\hline Nurses Choices' About Devices of & & \\
\hline $\begin{array}{l}\text { Oxygen Therapy } \\
\text { Nasal canula or Nasal Continous Positive } \\
\text { Airway Pressure (nCPAP) }\end{array}$ & 36 & 45.0 \\
\hline Oxygen Hood & 36 & 45.0 \\
\hline Directly via the Incubator & 6 & 7.5 \\
\hline No answer & 2 & 2.5 \\
\hline $\begin{array}{l}\text { Factors Influencing the Decision to } \\
\text { Initiate Oxygen Therapy* }\end{array}$ & & \\
\hline Fall in the value ofSpO & 46 & 57.5 \\
\hline Respiratory distress & 32 & 40.0 \\
\hline Physician's request & 30 & 37.5 \\
\hline
\end{tabular}

Factors to Determine Concentration and Flow Rate of Oxygen Therapy*

$\begin{array}{lrr}\text { Value of } \mathrm{SpO}_{2} & 52 & 65.0 \\ \text { Physician's request } & 31 & 38.8 \\ \text { Cardiovascular status of the baby } & 4 & 5.0\end{array}$

Factors to Determine Efficacy of Oxygen Therapy*

$\begin{array}{lll}\text { Value of } \mathrm{SpO}_{2} & 63 & 78.8 \\ \text { Blood gases } & 42 & 52.5\end{array}$

First Practices When a Fall in the Value of $\mathrm{SpO}_{2}$ in the Neonates*

$\begin{array}{lrr}\text { Administration of oxygen therapy } & 57 & 71.1 \\ \begin{array}{l}\text { Ensure air way patency and give position } \\ \text { for neonatale's safety }\end{array} & 32 & 39.9 \\ \begin{array}{l}\text { Tactile stimulus } \\ \text { To inform the physician }\end{array} & 16 & 19.9 \\ & 4 & 5.0\end{array}$

The Most Important Thing During Neonatal Oxygen Therapy

$\begin{array}{lrr}\text { The amount of oxygen } & 35 & 43.8 \\ \text { The value of } \mathrm{SpO}_{2} & 9 & 11.2 \\ \text { Humidification } & 9 & 11.2 \\ \text { No answer } & 27 & 33.6\end{array}$

*This question is marked more than one option. 
Table 3. Nurses' levels of knowledge about administration of oxygen therapy

\begin{tabular}{|c|c|c|c|}
\hline Questions & $\begin{array}{c}\text { Correct } \\
\text { Answers } \\
\text { n }(\%)\end{array}$ & $\begin{array}{c}\text { Incorrect } \\
\text { Answers } \\
\text { n }(\%)\end{array}$ & $\begin{array}{c}\text { Not Answered } \\
\text { n (\%) }\end{array}$ \\
\hline $\begin{array}{l}\text { How much oxygen is received by the neonates when administered } \\
\text { oxygen therapy at a flow rate of } 1 \mathrm{~L} / \mathrm{min} \text { ? }\end{array}$ & $7(8.8)$ & $53(66.2)$ & $20(25.0)$ \\
\hline $\begin{array}{l}\text { Is there any changing in the oxygen amount received by the neonate } \\
\text { according to using different devices for oxygen therapy? }\end{array}$ & $57(71.2)$ & $11(13.8)$ & $12(15.0)$ \\
\hline $\begin{array}{l}\text { What is the oxygen flow rate } \mathrm{L} / \mathrm{min} \text { for administration high flow } \\
\text { oxygen therapy? }\end{array}$ & $1(1.3)$ & $66(82.5)$ & $13(16.2)$ \\
\hline $\begin{array}{l}\text { What is the oxygen flow rate } \mathrm{L} / \mathrm{min} \text { for administration low flow } \\
\text { oxygen therapy? }\end{array}$ & $4(5.0)$ & $64(80.0)$ & $12(15.0)$ \\
\hline What is normal $\mathrm{SpO}_{2}$ value range for term neonates? & $18(22.5)$ & $58(72.5)$ & $4(5.0)$ \\
\hline What is normal $\mathrm{SpO}_{2}$ value range for preterm neonates? & $10(12.4)$ & $67(83.8)$ & $3(3.8)$ \\
\hline Which fluid is used for humidifying the oxygen? & $76(95.0)$ & $3(3.8)$ & $1(1.2)$ \\
\hline What is the frequency for checking of humidifier? & $11(13.8)$ & $58(72.4)$ & $11(13.8)$ \\
\hline How often rate of oxygen flow is checked? & $40(50.0)$ & $22(27.5)$ & $18(22.5)$ \\
\hline Is there any need to raise the neonates' heads during oxygen therapy? & $57(71.3)$ & $17(21.3)$ & $6(7.4)$ \\
\hline Is pre-oxygenation performed before endotracheal aspiration? & $62(77.5)$ & $18(22.5)$ & $-(-)$ \\
\hline $\begin{array}{l}\text { Is flow rate of oxygen gradually reduced while finishing oxygen } \\
\text { therapy? }\end{array}$ & $79(98.8)$ & $1(1.2)$ & $-(-)$ \\
\hline
\end{tabular}

When the amount of oxygen changing for gestational age was asked, the correct answers for term neonates oxygen saturation amount were $22.5 \%$ and $12.4 \%$ for premature neonates. Type of fluid used for humidifying the oxygen $(95.0 \%)$, the frequency for checking humidifiers (13.8\%) and checking oxygen flow (50.0\%) was known correctly. The question concerning the need to raise the neonates' heads during oxygen therapy was answered correctly by $71.3 \%$ of participants. Questions about "performing pre-oxygenation before endotracheal aspiration" and "reducing gradually flow rate of oxygen while stopping oxygen therapy" were correctly answered by, respectively, $77.5 \%$ and $98.8 \%$ of nurses (Table 3).

When the most frequent complications for neonatal oxygen therapy were asked, nurses identified ROP (90.1\%) and respiratory depression (7.6\%). Also five nurses were unable to answer this question. Complications related to oxygen therapy that occurred in their units were asked; 39 nurses indicated ROP $(48.8 \%)$ and 4 nurses (5.0\%) reported that there were not seen any complication in their units. Furthermore, 37 nurses $(46.3 \%)$ said they didn't know anything about this issue.

\section{DISCUSSION}

The extent and quality of neonatal services has a vital importance with regard to neonatal morbidity and mortality. Neonatal mortality rate in our country is 7 per thousand (19). Even though this index has been seriously reduced over the years, the desired level has not been reached yet. Developing of neonatal services (in term $\mathrm{s}$ of patient care, infrastructure development, quality and numbers of personnel) is of paramount importance in this respect (20). Neonatal nurses, who carry a heavy responsibility in providing these services, need to have the special knowledge and skills required in this particular field alongside their basic professional capabilities. But in our country, special division of nursing training like neonatal nursing is not fully developed. The only step taken in this area is the neonatal certificate program of the Ministry of Health with limited number of participants. This is supported by the data obtained from this study. Similarly, it is found that a few nurses participated in the neonatal nursing 
certificate program. More than a half of nurses had attended in the neonatal resuscitation program.

Oxygen therapy is one of the common neonatal care acts. In order to provide proper care and ensure high quality in neonatal oxygen therapy, it is necessary to codify it in relevant protocols, spread awareness of existing protocols and periodically conduct departmental programs (18). Written protocols about oxygen therapy should include target saturation values, situations that need oxygen therapy and appropriate methods of oxygen therapy according to neonates' clinical situation. Also related issues like recording and finishing of oxygen therapy must be mentioned in the protocols. On the subject, most of developed countries have protocols, procedures and periodic revisions about them. Health care professionals such as neonatologists, neonatal nurses, physical therapists, academic practitioners may take part in drafting and reviewing these protocols in these countries. Appropriate protocols must allow the development and reinforcement of neonatal health services, unfortunately there is no generally accepted formal protocol about oxygen therapy in Turkey. Hospital management is responsible for creating protocol or procedure about oxygen therapy according to their vision and mission. Similarly, such a protocol was not encountered in the NICUs included in our study. The nurses in our study expressed a similar view, and a majority expressed the thought of including physicians in this process.

Different methods such as direct administration in the incubator and nasal cannula are used to provide oxygen support in neonatal units $(11,13)$. The neonate's condition, physician's preferences, accessibility of the method, economics, familiarity to devices of oxygen therapy for health care profession have an influence on choosing the method of oxygen therapy. For example, in a study of decision making with regard to the equipment needed for oxygen transport, $98.1 \%$ of nurses expressed paying primarily attention to the patient's comfort and $1.9 \%$ to the cost of therapy (8). The mentioned study indicated that oxygen delivery into the incubator was widely used, while nurses more frequently preferred to use nasal cannula, nCPAP and oxygen hood as a method. When examining the published reports on methods preferred in neonatal intensive care units, data are found to indicate that using humidified high-flow nasal cannula (HHFNC) is preferred over nCPAP as a result of being ease of handling and of nursing care (11). For example, in a study, the preference for HHFNC as an oxygen delivery system found among neonatologists was attributed to ease of administration in the newborn $(86.0 \%)$, easier adaptation on the part of the newborn $(84.0 \%)$, reduced nasal trauma (73.0\%), nurse satisfaction (70.0\%), support of mother-child bonding (68.0\%) and patient satisfaction $(53.0 \%)$ (13).

$\mathrm{SpO}_{2}$, which is called "the fifth vital sign", is very important in the process of decision and evaluating oxygen therapy (7). In most of the studies showed that $\mathrm{SpO}_{2}$ levels affect decision process of starting oxygen therapy and efficacy of it $(12,13,21)$.For example, Eastwood et al. (2009) found that adult intensive care units nurses used the $\mathrm{SpO}_{2}\left(\mathrm{SpO}_{2} \geq 95 \%\right)$ and arterial blood gas levels, which were determined by the physician, to evaluate effectiveness of oxygen administration. Another study showed that when there was an absence of physician's order, $93.5 \%$ of nurses decided to start oxygen therapy, to adjust flow rate and inspired oxygen concentration by themselves according to the basis of $\mathrm{SpO}_{2}$ or the partial oxygen pressure in the blood $(\mathrm{PaO} 2)$ (8). However, oxygenation of the patient should not be taken only on the basis of $\mathrm{SpO}_{2}$ in these processes, because $\mathrm{SpO}_{2}$ levels cannot inform us patient's blood $\mathrm{pH}$ or partial pressure of carbon dioxide $\left(\mathrm{PCO}_{2}\right)(7)$.

This study also indicated that in case of a fall in oxygen saturation, nurses first start oxygen therapy to neonates by their own decision and only a few participants started it after informing the physicians. These findings indicate that while neonatal intensive care 
nurses do give precedence to doctors' orders in routine situations, they decide autonomously in emergencies like decreasing in the levels of $\mathrm{SpO}_{2}$. Data of our study conform to published studies $(7,8)$.To sum up, well-trained neonatal intensive care nurses can properly manage the process of oxygen therapy which contains decision making, implementation and recording in nursing notes.

In our study, nurses gave importance to the amount of oxygen supplied to neonate, concentration of oxygen, humidification level and $\mathrm{SpO}_{2}$ values during the process of oxygen therapy. Our results also indicated that neonatal nurses had certain insufficiencies about oxygen administration and associated nursing care of it. Lack of experience and awareness in the medical and nursing aspects of oxygen therapy may lead to several undesirable effects, especially in the premature newborn. For example; using inappropriate nasal prongs and stabilizing devices can cause problems to neonates such as granulation, ulceration, necrosis, nasal vestibular stenosis and nasal deviation $(11,13,14,22)$. All these undesirable effects may be prevented by appropriate and thoughtful nursing care. Neonatal intensive care nurses should be more professional. Also they should focus on oxygen administration from a broader perspective.

This study showed wide-ranging differences in the level of knowledge of the nurses concerning devices for oxygen therapy and administration of it. Only a small proportion of the participants had answered the questions about "approximate amount of oxygen given to the neonate at $1 \mathrm{~L} / \mathrm{min}$ rate", "ranges of high and low flow rates $(\mathrm{L} / \mathrm{min})$ for oxygen therapy" and "frequency of controlling humidified systems" correctly. Most of them ignored the changings in amount of oxygen saturation according to gestational age. A majority answered correctly about variability of the oxygen dose according to administration system, type of the humidifier fluid, frequency of checking flow rate and stepwise reduction for weaning the patient off oxygen. This knowledge is essential to oxygen administration and supported by published evidence. For example, considering that hypoxemia is the most frequent complication of endotracheal aspiration, hyperoxygenation must be performed before and after such aspiration (23). A study indicated that $56.1 \%$ of nurses did administer oxygen before performing endotracheal aspiration (8). Preoxygenation for most NICU patient, but the level of preoxygenation required is not known. It is suggested that the amount of oxygen required to prevent hypoxemia be assessed on a case-by-case basis (24). Also, oxygen administered to the newborn without using humidified systems may cause dryness of the nasal mucosa and other related problems (17).Thickening of secretions and nasal irritation are prevented by warming and humidifying through humidified systems, which prevent the loss of moisture in the airways (25). A high percentage of the nurses in our study reported knowledge of ROP as a complication of neonatal oxygen therapy, and the fact that ROP was the most frequent complication in their own units. Literature showed that apart from prematurity and low birth weight, oxygen therapy also carries significant risk for ROP (26). All these findings show insufficient knowledge on oxygen concentration and treatment follow-up in neonatal units. They also show a need for written, evidence-based guidance for oxygen administration and related care.

\section{Conclusion}

Neonatal intensive care nurse has the duty of possessing the necessary knowledge and skills for oxygen administration, in the interest of patient safety. This study showed that neonatal nurses had adequate knowledge on some aspects of oxygen therapy like preoxygenation before endotracheal aspiration or reducing gradually flow rate of oxygen while stopping oxygen therapy. But they also had incomplete knowledge in some vital issues such as ranges of high or low flow rate for 
oxygen therapy. These results indicate a need education program about neonatal oxygen administration for nurses. In addition to this, we found that adequate protocols were needed to avoid errors during oxygen therapy. We recommend studies with larger samples depending on limitation of our study. Relevant investigations must be conducted to determine the current situation and identify the aspects that should be developed. Furthermore, the results of these studies should be shared with the Ministry of Health and the neonatal nurse associations in order to ensure handling of the topic in certificate and training programs. In addition we suggested an education for NICU nurses about oxygen therapy could be prepared in these hospitals.

\section{Conflict of interest}

The authors have no conflicts of interest.

This study was presented as a poster in 4 . Ulusal Pediatri Hemşireliği Kongresi. 22-25 Mayıs 2013. Adiyaman, Turkey.

\section{REFERENCES}

1. Alpay A, Uğurbaş H. Incidence and risk factors for retinopathy of prematurity in the West Black Searegion, Turkey. Turk J Pediatr. 2012;54:113-118.

2. Parke RL, McGuinnes SP, Dixon R, Jull A. Protocol for a randomised controlled trial of nasal high flow oxygen therapy compared to Standard care in patients following cardiac surgery: The HOT-AS study. Int J Nurs Stud. 2012;49:338-344.

3. Kernick J, Magarey J. What is the evidence for the use of high flow nasal cannula oxygen in adult patients admitted to critical care units? A systemic review. Aust. Crit. Care. 2010;23:53-70.

4. Ayhan H, Iyigun E, Taştan S, Orhan ME, Öztürk E. Comparison of two different oxygen delivery methods in early post operative period: randomized trial. J. Adv. Nurs. 2009;65(6):12371247.

5. Frey B, Shann F. Oxygen administration in infants. Arch Dis Child Fetal Neonatal Ed. 2003;88:84-88.

6. McGloin S. Administration of oxygen therapy. Nursing Standard. 2008; 22(21): 4648.
7. O'Driscoll BR, Howard LS, Davison AG. BTS guideline for emergency oxygen use in adult patients. Thorax. 2008;63(supple VI): 68.

8. Eastwood GM, Reade MC, Peck L, Baldwin I, Considine J, Bellomo R. Critical care nurses' opinion and self reported practice of oxygen therapy: a survey. Aust. Crit. Care. 2012;25:23-30.

9. Lloyd J, Askie LM, Tarnow-Mordi WO. Supplemental oxygen for the treatment of prethreshold retinopathy of prematurity. The Cochrane Collaboration. Published by John Wiley\&Sons, 1td, 2009; 2-20.

10. Saugstad OD. Optimal oxygenation at birth and in the neonatal period. Neonatology. 2007;91:319-322.

11. Manley BJ, Owen L, Doyle LW, Davis PG. High flow nasal cannulae and nasal continouous positive airway pressure use in non-tertiary special care nurseries in Australia and New Zealand. J Paediatr Child Health. 2012;48:16-21.

12. Eastwood G M, O'Connell B, Gardner A, Considine J. Patients' and nurses' perspectives on oxygen therapy: A qualitative study. J Adv Nurs.2009;65(3):631-641.

13. Hough JL, Shearman AD, Jardine LA, Davies M. Humidified high flow nasal cannulae: Current practice in Australasian nurseries a survey. J Paediatr Child Health. 2012;48:106-113.

14. Lampland AL, Plumm B, Meyers PA, Worwa CT, Mammel C. Observational study of humidified high-flow nasal cannula compared with nasal continous positive airway pressure. J Pediatr. 2009;154(2):177-82.

15. Lakshminrusimha S, Manja V, Mathew B, Suresh GK. Oxygen targeting in preterm infants: a physiologic interpretation. J Perinatol. 2015;35(1):8-15.

16. Ramji S., \& Saugstad, O.D., Jain A., (2015). Current concepts of oxygen therapy in neonates. Indian J Pediatr. 82 (1) , 46-52.

17. Woodhead DD, Lambert DK, Clark JM, Christensen RD. Comparing two methods of delivering high flow gas therapy by nasal cannula following endotracheal extubation: a prospective, randomized, masked, crossovertrial. J Perinatol. 2006;26:481- 485.

18. AARC Clinical Practice Guideline. Selection of an oxygen delivery device for neonatal and pediatric patients-2002 revision and update. Respiratory Care. 2002;47(6):707-716.

19. Turkey Demographic and Health Survey TDHS (Türkiye Nüfus ve Sağlık Araştırması TNSA) (2013) Hacettepe Üniversitesi Nüfus Etütleri Enstitüsü. Ankara. http://www.hips.hacettepe.edu.tr/TNSA_2013_ana_ rapor.pdf.

20. Dündar SA, Bayat M, Erdem E. Yenidoğan ünitelerinin düzeyleri ve organizasyonu.(The Levels 
and Organization of Neonatal Units). Sağlık Bilimleri Dergisi. 2011;20(2):137-142.

21. British Thoracic Society Home Oxygen Guideline Development Group 2009. BTS guideline for home oxygen in children. Thorax;64(Supple II): ii1-ii26.

22. McCoskey L. Nursing care guidelines for preventing of nasal break down in neonates receiving nasal CPAP. Adv Neonatal Care. 2008;8(2):116-124.

23. Demir F, Dramali A. Requirement for $100 \%$ oxygen before and after closed suction. J Adv Nurs. 2005;51(3):245-251.

24. Tume LN, Copnell B. Endotracheal suctioning of critically ill child. J pediatr Intensive Care. 2015;4:56-63.

25. Klerk A. Humidified high flow nasal cannula: Is it the new and improved CPAP? Adv Neonatal Care. 2008;8(2):98-106.

26. Ak P, Sur S, Pal J, Ak G. Incidience of Retinopathy of Prematurity and its association with oxygen therapy in preterm low birth weight babies. J Nepal Pediatr Soc. 2015; 35(3): 247-252. 